\title{
Gastric Carcinoid Tumors: \\ The Problems Encountered in Diagnosis and Treatment
}

\author{
Osman YUKSEL ${ }^{1}$, Hande KOKSAL ${ }^{1}$, Ozgur EKINCI ${ }^{2}$, Murat AKIN ${ }^{1}$, \\ Ersin OZDEMIR ${ }^{3}$, Zafer FERAHKOSE ${ }^{1}$ \\ ${ }^{1}$ Gazi University Faculty of Medicine, Department of Surgery \\ ${ }^{2}$ Gazi University Faculty of Medicine, Department of Pathology \\ ${ }^{3}$ Bayındır Hospital Department of Surgery, Ankara, TURKEY
}

\begin{abstract}
Gastric carcinoid tumors are rare tumors that originate from gastric enterochromaffin-like cells in the oxyntic mucosa and constitute 3.2-4\% of all carcinoid tumors. Herein, outcome of a single institution experience with gastric carcinoid tumors were evaluated retrospectively. The patients with gastric carcinoid tumors were analyzed with respect to their presenting signs and symptoms, serum gastrin level, imaging studies, operative procedures and outcome of 21 patients with gastric carcinoid tumor were enrolled in this study. Sixteen patients had type 1 and 5 had type IV gastric carcinoid tumors. Endoscopic biopsy was performed in 15 patients with type I and in 2 patients with type IV. Multifocal tumor was seen in 7 patients with type I. Preoperative serum gastrin levels were high in 11 patients with type I and 3 patients with type IV gastric carcinoid tumor. In the patients with type I gastric carcinoid tumor, endoscopic mucosal resection (EMR) was performed in 6 patients with only one tumor and the tumor size less than $1 \mathrm{~cm}$. In this group, 3 patients had relapse (50\%). Total gastrectomy was performed in all the patients with type IV gastric carcinoid tumor. The 5-year survival of type I and IV gastric carcinoid tumors were $69.1 \%$ and $48.6 \%$, respectively.
\end{abstract}

Keywords: Carcinoid tumor, Stomach, Hypergastrinemia, Chromogranin A

\section{ÖZET}

Mide Karsinoid Tümörleri: Tanı ve Tedavide Karşılaşılan Problemler

Midenin karsinoid tümörleri nadir olup mide mukozasında yerleşen enterokromafin hücrelerden köken alır ve tüm karsinoid tümörlerin \% 3,2- 4'ünü oluşturur. Burada tek bir merkezin mide karsinoid tümörlü hastaları retrospektif olarak değerlendirilip sonuçları sunulmuştur. Başvuru şikayetleri, bulgular, serum gastrin düzeyleri, görüntüleme çalışmaları, tedavi yaklaşımları ve sonuçları değerlendirilen 21 hasta çalışmaya dahil edilmiştir. Hastaların 16'sında tip I, 5'inde tip IV karsinoid tümör saptanmış, tip I mide karsinoid tümörlü 15 hastaya ve tip IV tümörlü 2 hastaya endoskopik biyopsi yapıımıştır. Tip I karsinoid tümörlü 7 hastada multifokal tümör saptanmıştır. Preoperatif serum gastrin düzeyleri tip I tümörlü 11 hastada ve tip IV tümörlü 3 hastada yüksek olarak bulunmuştur. Tip I mide karsinoid tümörlü hastalardan $1 \mathrm{~cm}$ boyutundan küçük tek bir tümörü olan 6 hastaya endoskopik mukozal rezeksiyon (EMR) uygulanmıştır. Bu gruptaki 3 hastada (\%50) nüks saptanmıştır. Tip IV mide karsinoid tümörlü tüm hastalara total gastrektomi uygulanmıştır. Beş yillık sağ kalım oranları tip I ve tip IV mide karsinoid tümörlü hastalarda sırasıyla \%69,1 ve \%48,6 olarak saptanmıştır.

Anahtar Kelimeler: Karsinoid tümör, Mide, Hipergastrinemi, Kromogranin A 


\section{INTRODUCTION}

Gastric carcinoid tumors are rare tumors that originate from gastric enterochromaffin-like (ECL) cells in the oxyntic mucosa. It constitutes $3.2-4 \%$ of all carcinoid tumors and consists of the following types: type I is associated with chronic atrophic gastritis, type II develops in patients with combined multiple endocrine neoplasia type I and the Zollinger-Ellison syndrome, and type III is sporadic. Although the pathogenesis of these tumors is not completely understood, hypergastrinemia has an important role in the development of types I and II. The multiple endocrine neoplasia type I gene loci may be involved in type II gastric carcinoid tumors. ${ }^{1-3}$ The other type (type IV) originates from non-ECL endocrine cells. This type is poorly differentiated and often highly malignant. It can be localized in any part of the stomach. ${ }^{2,4}$

The optimal treatment of gastric carcinoid tumors is still a matter of debate. The management of gastric carcinoids is largely dependent upon the subtype and size of the lesion. ${ }^{3}$

The goal of this retrospective study was to report the presentation, treatment, and outcome of a single institution experience with gastric carcinoid tumors.

\section{PATIENTS AND METHODS}

After appropriate Institutional Review Board approval, the patients diagnosed to have gastric carcinoid tumors and treated surgically between the years May 1996-December 2007 in Gazi University and Bayındır Hospital were included in the study. These patients were analyzed with respect to their presenting signs and symptoms, serum gastrin level, imaging studies (endoscopy, endoultrasonography, computed tomography, and scintigraphy), operative procedures and outcome. Numerical data are summarized as median (range). Kaplan-Meier analysis was used to calculate the crude cumulative survival rates.

\section{RESULTS}

Between May 1996 and December 2007, 21 patients with gastric carcinoid tumors were enrolled in this study. The patients' demographic and clinic features were in Table 1.

Endoscopic biopsy was performed in 15 patients with type I and in 2 patients with type IV. Multifocal tumor was seen in 7 patients with type I. No multifocal tumor was determined in patients with type IV. In 2 patients with type I, metastatic disease

\begin{tabular}{|lll|}
\hline \multicolumn{2}{|l|}{ Table 1. The patients' demographic and clinic features } & \\
\hline Type of carcinoid & Type I $(n=16)$ & Type IV $(n=5)$ \\
\hline No of tumor $1 />1$ & $7 / 9$ & $1 / 4$ \\
Age (median) (range) & $50(32-66)$ & $54(30-70)$ \\
Female/Male & $12 / 4$ & $4 / 1$ \\
Tumor size (median) (range) & $2.1(0.2-3.0)$ & $2.8(1.3-8)$ \\
Anemia with no gastrointestinal bleeding & 8 & 3 \\
Flushing1 & - & $896(190-1402)$ \\
Serum gastrin levels (pg/mL) (median) (range) & $1379(163-2400)$ & 2 \\
Endoscopic biopsy & 15 & - \\
Multifocality & 7 & 1 \\
Liver metastasis & 1 & - \\
Carcinoid syndrome & 2 & - \\
Endoscopic mucosal resection & 9 & - \\
Surgical procedure & & 52 \\
Partial gastrectomy (antrectomy) & 3 & 5 \\
Total gastrectomy & 10 & - \\
Follow-up (median range-months) & 34 & \\
\hline
\end{tabular}


was determined. Preoperative serum gastrin levels were high in 11 patients with type I gastric carcinoid tumor and 3 patients with type IV gastric carcinoid tumor.

\section{Surgical Treatment}

In the patients with type I gastric carcinoid tumor, EMR was performed in 6 patients with only one tumor and the tumor size less than $1 \mathrm{~cm}$. In this group, 3 patients had relapse (50\%). The average relapse time was 18 months (range, 6-36 months). Partial gastrectomy (antrectomy) procedure was performed after relapse. Total gastrectomy $(n=7)$ and $\operatorname{EMR}(n=3)$ were performed in the type 1 gastric carcinoid tumor patients with more than one tumor or the tumor size higher than $1 \mathrm{~cm}$. No recurrence was seen in the patients performed total gastrectomy. However, recurrence was determined in 3 patients performed EMR. The average relapse time was 16 months (range, 6-24 months). Total gastrectomy was performed to the patients with recurrence. All patients with type IV gastric carcinoid tumor underwent surgery for total gastrectomy.

Outcome: The 5-year survival of type I and IV gastric carcinoid tumors were $69.1 \%$ and $48.6 \%$, respectively.

\section{DISCUSSION}

Carcinoid tumors usually originate in hormoneproducing cells that line in the small intestine or other cells of the digestive tract. Gastrointestinal carcinoid tumors grow slowly. Most of them occur in the appendix, small intestine, and rectum. It is common to develop more than one tumor at the same time in the small intestine. Gastric carcinoid tumors are rare tumors and constitute $3.2-4 \%$ of all carcinoid tumors. The increased use of endoscopy and advances in imaging has led to a relative increase in detection of gastric carcinoid tumors recently. ${ }^{1-3}$

Gastric carcinoid tumors consist of the following types: type I gastric carcinoid tumor develops from ECL cells and is the most common type of gastric carcinoid tumor. It is associated with hypergastrinemia and is situated in corpus or fundus. They are usually small (1 cm or less) and often multicentric.
This type has benign behavior and rarely metastasizes. It occurs within the setting of chronic atrophic gastritis with achlorhydria-induced hypergastrinemi. ${ }^{2-4}$ Type II, similar type I, develops from ECL cells and the least common type. It can be associated with hypergastrinemia and MEN-1 syndrome. This type localize in corpus or fundus. The tumors are multicentric and their sizes are $1 \mathrm{~cm}$ or less. It has benign behavior and the overall survival is related more with the underlying MEN-1 syndrome than gastric carcinoid tumor. ${ }^{2-4}$ Type III gastric carcinoid tumors develop from ECL cells. In this type, serum gastrin levels are generally normal. The tumor, situated in corpus or fundus, is solitary and larger. Type III gastric carcinoid tumors are often highly malignant and the overall 5-year survival rates are less than $50 \% .^{2.4}$ Type IV gastric carcinoid tumors develop from other endocrine cells. It is located in any part of the stomach. The tumor is generally solitary and larger. They have often highly malignant behavior. ${ }^{2 \cdot 4}$

In our study, type I gastric carcinoid tumor was the most common type. The other type was type IV.

Patients with gastric carcinoid tumors have nonspecific symptoms such as pain or abdominal mass. These tumors are known to secrete serotonin and other histamine like substances. Carcinoid syndrome occurs when the load of secreted serotonin and histamine exceeds the metabolizing capacity of monoamine oxidase present in the liver and lung. The patients with gastric carcinoid tumors can be diagnosed at screening with gastroscopy because of atrophic gastritis. ${ }^{1.5}$

Gastrin, secreted by antral G-cell, causes ECL cells to release histamine and is a potent trophic agent. ${ }^{3,6-8}$ Gastrin level is detected to be high in conditions of increased gastric acidity (such as Zolinger-Ellison syndrome) and detected to be low in conditions of reduced gastric acidity (such as atrophic gastritis, use of gastric acid inhibitors). Especially, increased serum gastrin level can be seen in type I and II gastric carcinoid tumors.

In this study, the patients' major symptom or sign were epigastric pain and anemia without bleeding. Gastric carcinoid tumor was diagnosed in $81 \%$ of patients at screening with gastroscopy. Flushing was also one of the symptoms in one patient with type I gastric carcinoid tumor. 
High levels of different amines and peptides may be determined in the gastric carcinoid tumors. Today, plasma chromogranin is the primary screening tool. ${ }^{9}$ The urine levels of the peptides, amines and/or their degradation products may be used. However, they are less sensitive than their plasma measurements. ${ }^{9,10}$ Only serum gastrin level could be studied in the study. Preoperative serum gastrin levels were high in 11 patients with type I gastric carcinoid tumor and 3 patients with type IV gastric carcinoid tumor.

In a histochemical study of the gastric carcinoids, majority of the tumors are found to be confined to the mucosa and submucosa. Also, chromogranin and argyrophilic positivity are noticed. ${ }^{2,11}$ Immunohistochemistry with chromogranin A ( $\mathrm{CgA})$ and synaptophysin assessment is of relevance in identifying hyperplasia, dysplasia and malignant transformation of ECL cells. Also, immunohistochemical determination of the proliferative index with Ki67 and evaluation of the mitotic index, by counting number of mitosis per 10 high-power fields, are mandatory, with a negative prognostic meaning when $\mathrm{Ki}-67$ is $>2 \%$ and mitotic index is $>2 .{ }^{12} \mathrm{In}$ our cases the tumor size were ranged from 0.2 to 3 $\mathrm{cm}$ in the type I and 1,3 to $8 \mathrm{~cm}$ in the type IV gastric carcinoid tumors. Multifocality of the tumor were found in 7 patients with type I gastric carcinoid tumor. In these patients, in endoscopic biopsy invasion of muscularis propria and negative prognostic index was reported.

The treatment choice is dependent upon the type, size and number of the tumors. In type I gastric carcinoid tumors with chronic atrophic gastritis and hypergastrinemia, EMR can be initial treatment of choice if the tumors are smaller than $1 \mathrm{~cm}$ and not extending beyond the submucosa and are fewer than five in number. ${ }^{23,13}$ After EMR, the patients should be performed endoscopy regularly every 6 to 12 months. If recurrence is seen, wide surgical resection such as partial gastrectomy, antrectomy or total gastrectomy can be performed, depending on the extention of the disease. ${ }^{3}$ Type IV tumors consist of poorly differentiated endocrine carcinomas and mixed exocrine-endocrine carcinomas. Atrophic gastritis has been seen in up to $50 \%$ of these patients. The tumors are usually larger than $5 \mathrm{~cm}$, often ulcerating and surgically unresectable. The prognosis is poor, with a median survival of only 8 months reported in the literature. ${ }^{14}$ In these patients, wide surgical resection such as total gastrectomy should be performed.

In this study, EMR was performed in 6 patients with type I gastric carcinoma with only one focus and the tumor size less than $1 \mathrm{~cm}$. The recurrence rate was 50\% and average recurrence time was 18 months, and antrectomy procedure was performed after relapse. Total gastrectomy $(\mathrm{n}=7)$ and EMR $(\mathrm{n}=3)$ were performed in the patients with more than one tumor or the tumor size higher than $1 \mathrm{~cm}$. No recurrence was seen in the patients after total gastrectomy. However, recurrence was determined in 3 patients performed EMR. The average relapse time was 16 months. Patients with recurrence underwent surgery for total gastrectomy also. Total gastrectomy was performed in all the patients with type IV gastric carcinoid tumor as the first choice of surgery.

The patients with metastatic disease have poor prognosis. The medical treatment of the metastatic gastric carcinoid tumor is the same as for the other metastatic neuroendocrine tumors. The somatostatin analogues, $\alpha$-interferon, and different combinations of chemotherapeutic agents can be used. However, it is difficult to change their same poor outcome. ${ }^{3,15-17}$

The 5-year survival of type I and IV gastric carcinoid tumors were $69.1 \%$ and $48.6 \%$, respectively in our study.

In conclusion, for long term survival, the patients with carcinoid tumors should be performed an effective preoperative evaluation and an optimal management protocol.

\section{REFERENCES}

1. Modlin IM, Sandor A. An analysis of 8305 cases of carcinoid tumors. Cancer 79: 813-29, 1997.

2. Modlin IM, Lye KD, Kidd M. Carcinoid tumors of the stomach. Surg Oncol 12: 153-172, 2003.

3. Mulkeen A, Cha C. Gastric carcinoid. Curr Opin Oncol 17: 1-6, 2005.

4. Borch K, Ahrén B, Ahlman H, et al. Gastric carcinoids: biologic behavior and prognosis after differentiated treatment in relation to type. Ann Surg 242: 64-73, 2005. 
5. Burkitt MD, Pritchard DM. Review article: Pathogenesis and management of gastric carcinoid tumours. Aliment Pharmacol Ther 24:1305-20, 2006.

6. Hakanson R, Tielemans $Y$, Chen D, et al. Time-dependent changes in enterochromaffin-like cell-kinetics in stomach of hypergastrinemic rats. Gastroenterology 105:15-21, 1993

7. Bordi C, Dadda T, Azzoni C, et al. Hypergastrinemia and gastric enterochromaffin- like cells. Am J Surg Pathol 19:S8-S19, 1995.

8. Hakanson R, Sundler F. Proposed mechanism of induction of gastric carcinoids-the gastrin hypothesis. Eur J Clin Invest 20:S65-S71, 1990.

9. Modlin I, Tang L. The gastric enterochromaffin-like cell: an enigmatic cellular lesion. Gastroenterology 111:783-810, 1996.

10. Gough D, Thompson G, Crotty T, et al. Diverse clinical and pathologic features of gastric carcinoid and the relevance of hypergastrinemia. World $J$ Surgery 18: 472-480, 1994.

11. Thomas RM, Baybick JH, Elsayed AM, Sobin LH. Gastric carcinoids: an immunohistochemical and clinicopathologic study of 104 patients. Cancer 73: 2053-2058, 1994.

12. Massironi S, Sciola V, Spampatti MP, et al. Gastric carcinoids: between underestimation and overtreatment. World J Gastroenterol 15: 2177-2183, 2009.

13. Ichikawa J, Tanabe S, Koizumi W, et al. Endoscopic mucosal resection in the management of gastric carcinoid tumors. Endoscopy 35: 203-206, 2003.

14. Pasieka JL. Carcinoid tumors. Surg Clin North Am 89: 1123-1137, 2009.

15. Kaltsas GA, Besser GM, Grossman AB. The diagnosis and medical management of advanced neuroendocrine tumors. Endocr Rev 25: 458-511, 2004.

16. Garland J, Buscombe JR, Bouvier C, et al. Sandostatin LAR (long-acting octreotide acetate) for malignant carcinoid syndrome: a 3-year experience. Aliment Pharmacol Ther 17: 437-444, 2003.

17. Schnirer II, Yao JC, Ajani JA. Carcinoid-a comprehensive review. Acta Oncol (Madr) 42: 672-692, 2003.

\section{Correspondence:}

Dr. Osman YÜKSEL

Gazi Üniversitesi Tıp Fakültesi Genel Cerrahi Anabilim Dalı

06500 Beşevler ANKARA / TURKEY

Tel / Fax: (+90.312) 2025728

e-mail: yukselo@gazi.edu.tr 